\title{
A Study on the Correlation between RMB Exchange Rate and Stock Fluctuation in China
}

\author{
Bo Wang \\ Shanghai University \\ Shanghai, China
}

\begin{abstract}
Since this year, there was drastic fluctuation in China's stock during 10 months, of which the closing price of SSE Composite Index rose from more than 3000 points in January to more than 5000 points in June, and then quickly fell to around 3500 points in a month, and kept fluctuation later. In August when the stock fell sharply, RMB exchange rate against U.S. dollar rose suddenly after maintaining around 6.1 for a long time so that RMB was devaluated rapidly. The correlation between stock and RMB exchange rate has been studied in this paper.
\end{abstract}

Keywords-exchange rate; stock index; VEC

\section{INTRODUCTION}

Since Reform of RMB exchange rate in 2005, floating exchange rate system has been implemented in China. In the past decade, the foreign exchange market and stock market have been strengthening and perfecting, and have been proved imperfect in view of the drastic stock fluctuations in 2008 and this year. It's necessary to research the correlation between them and give measures for stabilization foreign exchange market and stock market.

\section{LITERATURE REVIEW}

\section{A. Foreign Literatures}

The study on correlation between exchange rate and stock in foreign is earlier, for example, in 1980 Dorn Busch put forward flow-oriented model which was believed that the exchange rate fluctuation in a country had one-way impact on stock fluctuation, and furthermore affected the monetary circulation speed and enterprises competitiveness in the country through import and export trade and asset flow, and finally affected domestic stock through taking influence on the actual output of the country. In 1983 Branson put forward stock-oriented model which was believed that the change of asset price shall be taken into account when investors taking investment portfolio, so as to cause the capital flow and affect money demand and supply relationship, which was important that the relationship between stock and exchange rate was perceived as positive correlation. In 1999, Izan present stock parity theory which is focused on parity analysis for stock and foreign exchange market, with a conclusion that currency appreciation in a country would lead to stock price decline in a weak parity relationship.
In the empirical study on the correlation between RMB exchange rate and stock price, some researchers believed that there was a two-way causality between them. For example, Jin Jihao (2003) researched the co-integration relationship among stock price, exchange rate, industrial added value, interest rate and so on, using co-integration test method and USA monthly data. Daniel (2004) researched the causality between exchange rate and stock price in EU and the United States using the methods of co-integration, error correction, Granger test etc. The results showed that there was a clear long-term or short-term causality between them which changed in different periods. Patan (2006) researched the exchange rate and stock in India, found that there was correlation between them, however, which was a one-way causality from exchange rate to stock price.

\section{B. Domestic Literatures}

The domestic researchers also have been studying on correlation between foreign exchange market and stock market. In the study of Qin Yiqun(2005), discussed the impact of RMB appreciation on asset prices in China by comparing between China and developed countries, came a conclusion that when there was RMB appreciation expectation, a large number of foreign capitals would inflow which could cause impact on capital market of China. Zhou Mei and so on (2007) researched the influence on domestic stock from RMB appreciation through transmission media, and drawn a conclusion that RMB appreciation would be conducive to economic development and stock development of China for long-term, but also brought instability risk to stock market. Li Zheguang and so on (2007) researched the data after reform of RMB exchange rate using co-integration method, found that there was a reverse correlation between exchange rate and stock index. Guo Fuchun and so on (2007) researched the transmission media between exchange rate and stock using Granger causality method, came a conclusion that the role of transmission media between stock market and foreign currency market in China was weak, far less than the developed countries, of which some was not playing roles.

\section{EMPIRICAL ANALYSIS}

\section{A. Variable Selection}

Floating exchange rate system has been used in China in which $\mathrm{RMB}$ exchange rate is mainly formed in view of RMB 
exchange rate formation reference proportion, the proportion of foreign trade, domestic economic strength and other factors. The middle rate of RMB against U.S. dollar published by SAFE has been used in this paper. Now there are Shanghai Stock Exchange, Shenzhen Stock Exchange, and A-share, B-share, H-share indexes in China. Since the A-share index is the most representative, the closing price of A-share index is chose as the representative of stock fluctuation in this paper. The variables are set as follows:

RMBRATE: Mid-point of RMB against dollar

SASTOCK : A-share closing price of Shanghai Composite Index

\section{B. Empirical Test}

Before the empirical test, the linear graph of RMBRATE and SASTOCK has been discussed firstly, as shown in Fig.31 , of which the right side is SASTOCK and the left side is RMBRATE, and the data come from January 5, 2015 to November 4, 2015. Fig.3-1 shows that there is a trend on the whole of reverse fluctuations between RMBRATE and SASTOCK, but same direction fluctuation in some times, so that there are different fluctuations trend between them in different periods.

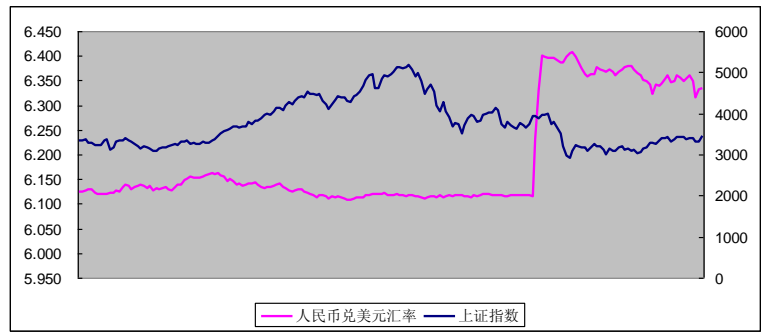

Fig. 1. Linear graph of RMBRATE and SASTOCK

\section{Stationary Test}

Since RMBRATE and SASTOCK both are time series in this paper, there is a need to carry out a stationary test before co-integration test so as to ensure co-integration test and Granger causality test hereunder. The sequences of RMBRATE and SASTOCK are tested using ADF method in this paper, if they are unstable, take further test on higher order. The software of Eviews is used to test in this paper. The results are shown in "Table I".

TABLE I. ADF TEST RESULTS OF RMBRATE AND SASTOCK

\begin{tabular}{|c|c|c|c|c|c|}
\hline $\begin{array}{l}\text { Series } \\
\text { Name }\end{array}$ & $\begin{array}{c}\text { Statistic } \\
\text { value of } \\
\text { ADF }\end{array}$ & $\begin{array}{c}1 \% \text { of } \\
\text { critical } \\
\text { value }\end{array}$ & $\begin{array}{c}5 \% \text { of } \\
\text { critical } \\
\text { value }\end{array}$ & $\begin{array}{c}P \\
\text { value }\end{array}$ & $\begin{array}{c}\text { Conclu } \\
\text { sion }\end{array}$ \\
\hline $\begin{array}{l}\text { RMBRAT } \\
\text { E }\end{array}$ & -1.329062 & -3.462901 & $\begin{array}{l}- \\
2.875752\end{array}$ & 0.6160 & $\begin{array}{l}\text { unstabl } \\
\text { e }\end{array}$ \\
\hline SASTOCK & -1.213579 & -3.463067 & $\begin{array}{l}- \\
2.875825\end{array}$ & 0.6686 & $\begin{array}{l}\text { unstabl } \\
\text { e }\end{array}$ \\
\hline $\begin{array}{l}\text { RMBRAT } \\
\text { E of first } \\
\text { order }\end{array}$ & -7.710309 & -3.462901 & $\begin{array}{l}- \\
2.875752\end{array}$ & 0.0000 & stable \\
\hline $\begin{array}{l}\text { SASTOCK } \\
\text { of first } \\
\text { order }\end{array}$ & -11.13733 & -3.463067 & $\overline{2} .875825$ & 0.0000 & stable \\
\hline
\end{tabular}

"Table I" shows time series of RMBRATE and SASTOCK and respective ADF unit root test results after first order difference. For the variable RMBRATE, after taking an ADF test, the results show that the P value of time series is significantly greater than 0.05 , which is mean that the ADF statistic value is less than the absolute value below $5 \%$ of the critical value, therefore the sequence is unstable. However, after taking first order difference, the new $\mathrm{P}$ value is far less than 0.05 , which is mean that the ADF statistic value is more than the absolute value below $5 \%$ of the critical value, therefore the sequence is a first order stationary sequence. For the variable SASTOCK, after an $\mathrm{ADF}$ test, the $\mathrm{P}$ value is also more than 0.05 , which is mean that the ADF statistic value is less than the absolute value below $5 \%$ of the critical value, therefore the sequence is unstable. After taking first order difference, the new $\mathrm{P}$ value is less than 0.05, which is mean the sequence is also a first order stationary sequence. After an ADF test, it is concluded that the variables of RMBRATE and SASTOCK are same order integration time series. The conclusion shows that both sequences meet the conditions of co-integration test, and can be taken co-integration test further.

\section{Co-integration Test}

As mentioned earlier, in view of the more wide range of Johansen co-integration test than Engel-Granger cointegration test, the Johansen co-integration test is used in this paper to test RMBRATE and SASTOCK with the results as shown in "Table II".

TABLE II. CO-INTEGRATION TEST RESULTS OF RMBRATE AND SASTOCK

\begin{tabular}{|l|c|c|c|c|}
\hline $\begin{array}{c}\text { co-integration } \\
\text { number }\end{array}$ & $\begin{array}{c}\text { Eigen- } \\
\text { value }\end{array}$ & $\begin{array}{c}\text { Statistic } \\
\text { value of T }\end{array}$ & $\begin{array}{c}\text { 5\% of critical } \\
\text { value }\end{array}$ & $\begin{array}{c}\text { P } \\
\text { value }\end{array}$ \\
\hline None & 0.030619 & 6.935280 & 15.49471 & 0.5852 \\
\hline At most 1 & 0.003921 & 0.777975 & 3.841466 & 0.3778 \\
\hline
\end{tabular}

"Table II" shows that using the data from January 5, 2015 to November 4, 2015, and assumed without cointegration relationship, the $\mathrm{P}$ value is more than 0.05 , which is mean there is none co-integration relationship. However other researchers all think there is a co-integration relationship between them. The different result is mainly attributed to data error. Although floating exchange rate system used in China, the exchange rate is strictly controlled by government, which is around 0.05 with little fluctuation during April 2015 to January 2015, and appears large fluctuation from August 2015. Therefore the data of two months before and after August, from June 12, 2015 to November 4, 2015, has been used in ADF test of which results shows that both RMBRATE and SASTOCK are same order integration sequences. Then another co-integration test is carried out using new data. The results are shown in "Table III".

TABLE III. NEW CO-INTEGRATION TEST RESULTS OF RMBRATE AND SASTOCK

\begin{tabular}{|l|l|l|l|c|}
\hline $\begin{array}{c}\text { Co-integration } \\
\text { number }\end{array}$ & $\begin{array}{c}\text { Eigen- } \\
\text { value }\end{array}$ & $\begin{array}{c}\text { Statistic } \\
\text { value of T }\end{array}$ & $\begin{array}{c}\text { 5\% of } \\
\text { critical value }\end{array}$ & $\begin{array}{c}\text { P } \\
\text { value }\end{array}$ \\
\hline None & 0.184411 & 21.42792 & 15.49471 & 0.0057 \\
\hline At most 1 & 0.026214 & 2.470401 & 3.841466 & 0.1160 \\
\hline
\end{tabular}


"Table III" shows that, when null hypothesis is no cointegration relationship, the $\mathrm{P}$ value is less than 0.05 , and the hypothesis is rejected, which is mean there is co-integration relationship; when null hypothesis is one co-integration relationship at most, the $\mathrm{P}$ value is more than 0.05 , and the hypothesis is accepted, which is mean there is a cointegration relationship between RMBRATE and SASTOCK. The Grainger causality test and VEC model building can be carried out hereunder.

\section{E. Granger Causality Test}

As mentioned earlier, there is a co-integration relationship between RMBRATE and SASTOCK after reducing data, and then Granger causality test can be carried out for the two variables. The results are shown in "Table IV".

TABLE IV. GRANGER CAUSALITY TEST RESULTS OF RMBRATE AND SASTOCK

\begin{tabular}{|c|c|c|c|}
\hline Null hypothesis & $\begin{array}{c}\text { Statistic } \\
\text { value of } F\end{array}$ & $P$ value & $\begin{array}{c}\text { Lag } \\
\text { length }\end{array}$ \\
\hline $\begin{array}{l}\text { SASTOCK is not the Granger } \\
\text { reason of RMBRATE }\end{array}$ & 0.53119 & 0.5898 & 2 \\
\hline $\begin{array}{l}\text { RMBRATE is not the Granger } \\
\text { reason of SASTOCK }\end{array}$ & 4.66872 & 0.0118 & 2 \\
\hline $\begin{array}{l}\text { SASTOCK is not the Granger } \\
\text { reason of RMBRATE }\end{array}$ & 0.63072 & 0.5972 & 3 \\
\hline $\begin{array}{l}\text { RMBRATE is not the Granger } \\
\text { reason of SASTOCK }\end{array}$ & 3.53705 & 0.0180 & 3 \\
\hline $\begin{array}{l}\text { SASTOCK is not the Granger } \\
\text { reason of RMBRATE }\end{array}$ & 0.49377 & 0.7403 & 4 \\
\hline $\begin{array}{l}\text { RMBRATE is not the Granger } \\
\text { reason of SASTOCK }\end{array}$ & 3.55860 & 0.0099 & 4 \\
\hline $\begin{array}{l}\text { SASTOCK is not the Granger } \\
\text { reason of RMBRATE }\end{array}$ & 0.40166 & 0.8463 & 5 \\
\hline $\begin{array}{l}\text { RMBRATE is not the Granger } \\
\text { reason of SASTOCK }\end{array}$ & 3.10223 & 0.0131 & 5 \\
\hline $\begin{array}{l}\text { SASTOCK is not the Granger } \\
\text { reason of RMBRATE }\end{array}$ & 0.50415 & 0.8034 & 6 \\
\hline $\begin{array}{l}\text { RMBRATE is not the Granger } \\
\text { reason of SASTOCK }\end{array}$ & 2.49197 & 0.0295 & 6 \\
\hline $\begin{array}{l}\text { SASTOCK is not the Granger } \\
\text { reason of RMBRATE }\end{array}$ & 0.42561 & 0.8833 & 7 \\
\hline $\begin{array}{l}\text { RMBRATE is not the Granger } \\
\text { reason of SASTOCK }\end{array}$ & 3.52641 & 0.0025 & 7 \\
\hline $\begin{array}{l}\text { SASTOCK is not the Granger } \\
\text { reason of RMBRATE }\end{array}$ & 0.39286 & 0.9210 & 8 \\
\hline $\begin{array}{l}\text { RMBRATE is not the Granger } \\
\text { reason of SASTOCK }\end{array}$ & 4.45675 & 0.0002 & 8 \\
\hline $\begin{array}{l}\text { SASTOCK is not the Granger } \\
\text { reason of RMBRATE }\end{array}$ & 0.36319 & 0.9486 & 9 \\
\hline $\begin{array}{l}\text { RMBRATE is not the Granger } \\
\text { reason of SASTOCK }\end{array}$ & 4.08284 & 0.0003 & 9 \\
\hline $\begin{array}{l}\text { SASTOCK is not the Granger } \\
\text { reason of RMBRATE }\end{array}$ & 0.37344 & 0.9539 & 10 \\
\hline $\begin{array}{l}\text { RMBRATE is not the Granger } \\
\text { reason of SASTOCK }\end{array}$ & 3.75067 & 0.0005 & 10 \\
\hline
\end{tabular}

"Table IV" shows that under the situation of lag length set from 2 to 10 , when assume that SASTOCK is not the Granger reason of RMBRATE, all P are greater than 0.05 , which is mean that the null hypothesis is accepted; when assume that RMBRATE is not the Granger reason of SASTOCK, all $\mathrm{P}$ are less than 0.05 , which is mean that the dull hypothesis is rejected so that RMBRATE is the Granger reason of SASTOCK. We get the conclusion that there is a one-way causality between RMBRATE and SASTOCK, which is mean that RMB exchange rate has influence on stock price.

\section{F. VEC Model Analysis}

1) Optimal lag order selection. As previously mentioned, optimal lag order should be selected before building VEC model which is built on the basis of VAR model, using the criterions of LR test, FPE final error test, AIC information criterion, SC information criterion in Eviews, and comparing the test value under each order to determine the optimal lag order. The results are shown in "Table V".

In "TableV", the number marked “*” are minimum order in all orders, and the optimal lag order is 2 selected by three criterions in all four criterions. Importantly, since the lag order of VEC model is p-1 order of VAR model, and the optimal lag order of VAR model is 2 here, then the lag order of VVEC model is 1.

TABLE V. The RESUlts OF OPtIMAL LAG ORDER

\begin{tabular}{|c|c|c|c|c|c|}
\hline $\begin{array}{c}\text { La } \\
\mathrm{g}\end{array}$ & $\log L$ & LR & FPE & AIC & SC \\
\hline 0 & -531.4721 & NA & 837.6285 & 12.40633 & 12.46340 \\
\hline 1 & -300.5378 & 445.7567 & 4.276306 & 7.128787 & 7.300021 \\
\hline 2 & -281.4930 & 35.87519 & $3.014444^{*}$ & $\begin{array}{l}6.778907 \\
*\end{array}$ & $\begin{array}{l}7.064296 \\
*\end{array}$ \\
\hline 3 & -277.6669 & 7.029298 & 3.028052 & 6.782952 & 7.182497 \\
\hline 4 & -276.5167 & 2.059612 & 3.238178 & 6.849227 & 7.362927 \\
\hline 5 & -270.8479 & 9.887600 & 3.118896 & 6.810415 & 7.438272 \\
\hline 6 & -268.6528 & 3.726570 & 3.258624 & 6.852390 & 7.594402 \\
\hline 7 & -262.8114 & $9.645091 *$ & 3.129957 & 6.809567 & 7.665734 \\
\hline 8 & -260.3654 & 3.924944 & 3.256001 & 6.845707 & 7.816030 \\
\hline 9 & -258.0146 & 3.662857 & 3.397775 & 6.884060 & 7.968539 \\
\hline 10 & -254.5086 & 5.299789 & 3.455382 & 6.895548 & 8.094183 \\
\hline
\end{tabular}


2) VEC model and results. After the stationary test, cointegration test, and Granger causality test, VEC model is established and analyzed. In this paper, using the data come from June 12, 2015 to November 4, 2015, the results are shown in "Table VI".

In "Table VI", Co-integration Equation between RMBRATE and SASTOCK as follows:

\section{SASTOCK $=2753.665 *$ RMBRATE -20856.6}

From the Co-integration Equation above, we get:

\section{$\mathrm{ECM}=\mathrm{SASTOCK}-2753.665 * \mathrm{RMBRATE}+20856.6$}

In "Table VI", ECM coefficients are -0.154323 and $3.54 \mathrm{E}-06$, we can get vector error correct model equation through the results of VEC model as follows:

$\mathrm{D}(\mathrm{SASTOCK})=$ $0.154323 * \mathrm{ECM}+0.119618 * \mathrm{D}(\mathrm{SASTOCK}(-$ 1))+1045.036*D(RMBRA

\section{$\mathrm{TE}(-1))$}

The results show that RMBRATE has a positive impact on stock price, although the coefficient is large, but the data is RMB exchange rate against one dollar, so the impact is relatively weak, which is also related to the development of securities market in China.

TABLE VI. VEC MODEL RESUltS

\begin{tabular}{|l|l|l|}
\hline \multicolumn{1}{|c|}{ Cointegrating Eq: } & \multicolumn{1}{|c|}{ CointEq1 } & \\
\hline SASTOCK(-1) & 1.000000 & \\
\hline RMBRATE(-1) & 2753.665 & \\
\hline & $(579.179)$ & \\
\hline & {$[4.75443]$} & \\
\hline C & -20856.60 & \\
\hline Error Correction: & $\mathrm{D}(\mathrm{SASTOCK})$ & $\mathrm{D}(\mathrm{RMBRATE})$ \\
\hline CointEq1 & -0.154323 & $-3.54 \mathrm{E}-06$ \\
\hline & $(0.03537)$ & $(5.0 \mathrm{E}-06)$ \\
\hline & {$[-4.36363]$} & {$[-0.70818]$} \\
\hline D(SASTOCK(-1)) & 0.119618 & $6.89 \mathrm{E}-06$ \\
\hline & $(0.09542)$ & $(1.3 \mathrm{E}-05)$ \\
\hline & {$[1.25363]$} & {$[0.51133]$} \\
\hline D(RMBRATE(-1)) & 1045.036 & 0.570993 \\
\hline & $(632.521)$ & $(0.08938)$ \\
\hline & {$[1.65218]$} & {$[6.38846]$} \\
\hline C & -17.08563 & 0.001147 \\
\hline & $(11.6094)$ & $(0.00164)$ \\
\hline & {$[-1.47171]$} & {$[0.69899]$} \\
\hline
\end{tabular}

\section{CONCLUSION}

Through co-integration test, Granger causality test and VEC model for the two variables of RMBRATE and SASTOCK, the relationship between them is long-term cointegration, and one-way causality from RMBRATE to SASTOCK which is positive relationship, once RMBRATE raises (RMB devaluation), SASTOCK rise too. The relationship is weak because of the following aspects: firstly, media factor does not play an effective role; secondly, the exchange rate formation mechanism in China is unreasonable; finally, the stock price formation mechanism in China is also unreasonable.

\section{RECOMMENDATION ABOUT EXCHANGE RATE AND STOCK}

In order to stabilize exchange rate and stock price, firstly, new RMB exchange rate formation mechanism should be established with more reasonable and flexible, base on market supply and demand, changing the traditional mechanism of focusing on US dollar, such as emphasizing the role of market supply and demand for RMB exchange rate, adjusting the weight of a basket of currencies and the stability strategy for "no appreciation", in order to prevent excessive speculative capital inflow and outflow. Secondly, the media between foreign currency market and stock market should play a important role, in order to make the foreign trade play a better role, make RMB steady appreciation, expand imports and increase foreign investment, accelerate economic restructuring. Finally, strengthen risk control and supervision of securities market, especially, the international capital flows, to prevent a large number of foreign capital inflow and outflow, additionally improve the methods and measures of supervision.

\section{REFERENCES}

[1] Dornbusch, Fischer. Exchange Rates and the Current Account[J].AER, 1980,70(5): 960-971.

[2] Branson.W.H. Macroeconomic Determinants of Real Exchange Rate Risk[M]. in RJ.Herring Managing Foreign Exchange Rate Risk. Cambridge University Press,1983.108-115.

[3] Ong.Lilian, Izan,"Stocks and Currencies: Are they Related?" [J].Taylor and Francis Journal,1999,9(5):523-532.

[4] Hwang.J.K. The Relationship between Stock Prices and the Exchange Rates: Evidence from Canada, [J].International Advances in Economic Research, 1999, 5(4):397-388.

[5] Granger.C.W.J,Huang.B, and Yang,C.W."A Bivariate Causality between Stock Prices and Exchange Rate:Evidence from Recent Asian Flu" $[\mathrm{J}]$.The Quarterly Review of Economics and Finance,2000,40(3):337-354.

[6] Chen Ranfang. On the Interaction and Mutual Influence of Exchange Rate and Stock Prices[J]. Theory and Practice of Finance and Economics .2009.2

[7] Qin Yiqun. Analysis on the Influence of RMB Exchange Rate Appreciation on Capital Market [J]. Journal of Henan College of Financial Management Cadres.2005.3

[8] Cao Guangxi, Cui Weijun, Han Yan. Influence of RMB Exchange Rate Flexibility Adjustment on the Relations between the Foreign Currency and Stock Market of Our Country - based on Long Memory VAR- (BEKK) MVGARCH Model [J] Mathematical Statistics and Management .2014 .06

[9] Liu Ganzhou. Analysis on the Interaction Mechanism of Exchange Rate Fluctuations and Stock Market Price Fluctuations - and on the Countermeasures of China's Stock Market Stability under RMB Appreciation $[\mathrm{J}]$ Changyixi College of Finance and Economics2006.1.

[10] Liu Wei. The relevance of China's Securities Investment Funds with the Fluctuation of Stock Market and Bond Market - based on the Research of BEKK Model and Failure Test Method [J] Southern Finance .2011.11

[11] Zhu Xinrong, Zhu Zhenyuan. The Relevance of the RMB Currency Exchange Rate Fluctuations and Chinese Stock Prices Remuneration [J]. Financial Research .2008.11

[12] Zhang Lulu. On the Influence of RMB Appreciation on China's Stock Market [J]. Special Zone Economy.2007.3

[13] Ye Fu Jing. Study on RMB Exchange Rate Formation Mechanism [M] China Planning Press .2007 
[14] Fan Dejun. International Investigation of the Impact of Currency Appreciation on the Stock Market[J]. China Galaxy Securities .2006.12 